\title{
Addressing Employee Lawsuits
}

\author{
DAVID SHERWYN and PAUL E. WAGNER
}

For months you tried to save this employee. You gave him numerous second chances, you gave him a performance improvement plan, and you even put him on probation. Finally, after all the warnings, the low productivity, and the time and effort, you have no choice but to let the employee go. You agonized over the decision but knew it was right. Imagine your surprise when you received a letter in the mail today accusing you and your company of disability discrimination! You did not even know the employee was disabled. You are faced with the reality: All managers are, at one time or another, accused of discrimination. The purpose of this chapter is to help you respond to this complaint by: (1) defining the law; (2) explaining how discrimination claims are adjudicated; (3) discussing the Americans with Disabilities Act and sexual harassment; and (4) advising employers in the hospitality industry on how to avoid liability.

\section{What is the Law?}

There are four federal law statutes prohibiting discrimination. Title VII of the Civil Rights Act of 1964, as amended by the Civil Rights Act of 1991, covers employers with 15 or more employees and simply states that employers may not discriminate against applicants and employees because of color, race, national origin, religion, or gender. The Age Discrimination in Employment Act of 1967 (ADEA) states that employers with 20 or more employees may not discriminate against those who are over 40 years of age; the American with Disabilities Act of 1992 (ADA) prohibits discrimination by employers with more than 15 employees against those who are disabled, and Section 1981 of the Civil Rights Act of 1866 (1981, which covers all employers), states that black people have the same right to enter into contracts as white people. This statute, which came out of the Reconstruction era, is applied to race cases in employment. We refer to gender, color, religion, national origin, race, religion, age and disability as the "protected classes."

The first three statutes also prohibit retaliation against any person who invokes their protection. The prohibition against sexual harassment is a subset of sexual discrimination under Title VII. Many 
states, counties, and cities have their own antidiscrimination laws that add additional protected classes (e.g., sexual orientation, family status) and may provide for different damages or adjudication schemes. Because it is impossible to address the laws of all 50 states as well as municipalities, we will focus our analysis on federal law.

Under federal law, your company can be liable for your actions, but you cannot be held personally liable (so, no one can take your house or your car). That's the good news. The bad news is that in some states (New York, for example), you can be held personally liable for discrimination and harassment.

The damages that a plaintiff may recover consist of back pay (what plaintiffs would have earned less what they actually earned), reinstatement, compensatory damages, attorney's fees, and litigation costs. Under Title VII and the ADA, punitive damages are available if the conduct is reckless or malicious. These damages are capped depending on the number of employees, so, for example, punitive damages may not exceed $\$ 50,000$ for employers with fewer than 100 employees, whereas employers with more than 500 employees may be assessed as much as $\$ 300,000$. Under the ADEA, there are no punitive damages, but employees can recover double their back pay if the conduct was willful. The Civil Rights Act of 1866 allows for unlimited punitive damages. In addition, some jurisdictions allow for greater damages awards, such as the state of California and the city of New York.

Juries are not informed of damage caps. Thus, when you see a punitive damage award of millions of dollars in a discrimination case, one of three things is going on: (1) a state or local statute allowed greater damages; (2) it's a race case and the plaintiffs' lawyers were smart enough to invoke the Civil Rights Act of 1866; or (3) the damage award is meaningless and will be reduced in accordance with the cap.

The protected classes set forth in Title VII are, for the most part, fairly straightforward. Courts employ the plain meaning of the terms race, religion, and national origin. Still, there are some anomalies that are not obvious. For example, religion is not limited to established, traditional religions, and requires only that an employee possesses a true belief in the religion, however unusual. Title VII's protection against religious discrimination even extends to the belief in no religion. While the term sex as it appears in Title VII means gender, this protected class gets complicated because it includes sexual harassment. The ADEA is very simple-it protects those employees over the age of 40 . The ADA is not so simple. The ADA protects those who are disabled as defined by the law, but this definition presents a complex and moving target. In addition to prohibiting discrimination on account of disability, the ADA also requires employers to reasonably accommodate disabled employees. Finally, the fastest-rising 
discrimination claim is retaliation. Because of their relative complexity and prevalence for today's employers, we address sexual harassment and disability claims in detail in this chapter. While space constraints prevent us from examining retaliation, a foil discussion can be found in the 2009 Cornell Center for Hospitality Research law roundtable proceedings. ${ }^{1}$ Before we do that, however, we explain the process for filing and defending discrimination claims.

\section{The Adjudication Process}

To file a discrimination lawsuit, an employee must first file a charge of discrimination with either the Equal Employment Opportunity Commission (EEOC) or with a state or local agency authorized to investigate such claims. The agency with which the employee files a charge will investigate the allegation and try to settle the matter by having the employer remunerate, or reinstate the employee. If the employer and employee cannot agree on a settlement, the agency determines whether there is cause to believe that discrimination occurred. In most jurisdictions, if the agency finds "no cause," it still issues a "right to sue letter," allowing the employee to file an action in court (at this point, most employees walk away). If the agency finds cause, it may, depending on the agency, (1) issue a right to sue letter; (2) set the case for trial before its own administrative adjudication process; or (3) become the employee's counsel and file an action in federal court on the claimant's behalf

When a discrimination claim is filed, employers are required to complete a questionnaire and provide the investigating agency with a position statement. If the case is not resolved at the agency level and, instead, is adjudicated in court, the employer's attorneys' fees will almost always be in excess of $\$ 50,000$ and could exceed $\$ 500,000$, regardless of the merits of the case. Additional employer costs include the loss of productivity of other employees involved in the case, adverse publicity, and, of course, liability. Because defending discrimination lawsuits in federal court results in substantial costs to employers regardless of guilt, there is a strong incentive for employers to settle a case regardless of the worthiness of the plaintiff's claim.

The administrative procedures also provide investigators with incentives to settle cases. From the time they receive the case, investigators, who are often evaluated by the number of cases they resolve regardless of merit, push employers and employees to settle. This system has created a backlog of cases, cynicism about the enforcement of the discrimination laws, and what we refer to as "the discrimination de facto severance system." This occurs when employees file baseless discrimination charges because they know that their former employers are willing to pay a sum of money in order to 
avoid the costs and aggravation of defending the allegation. Smaller companies that do not have inhouse counsel or sophisticated human resource departments are especially vulnerable to this practice.

The EEOC, which encourages settlement at all the steps of the process, requires investigators to place each case into one of three categories before they even have discovered any facts. Cases placed in the $A$ or highest-priority classification fall within the national or local enforcement plan, which focus on class actions, systemic discrimination, and new areas of law. In such cases, the EEOC actually becomes the plaintiff in the case.

An example of a B case would be a charge involving only one or two employees who allege that they were not hired or were terminated because of their protected status. It-is not a class action, and there are no genuine issues of law present. Instead, the case turns on factual disputes. Such cases will never be labeled an A regardless of the strength of the evidence. B cases are investigated in due time, which means that the EEOC will eventually make a determination. However, these cases will not receive a priority classification and may still take approximately one year before the investigation is complete. Once completed, claimants who do not settle will have to begin the litigation process to adjudicate their claims. Litigation can take anywhere from two to eight years.

Cases placed in the $\mathrm{C}$ category are, for all intents and purposes, dead. The EEOC labels a case a $\mathrm{C}$ when it determines that the case is either frivolous or the agency lacks jurisdiction. On its face, this seems appropriate because it conserves scarce resources- and reduces de facto severance by discouraging potential plaintiffs that wish to capitalize on the employer's known incentives to settle.

\section{Statistical Analysis of the EEOC's Case Handling}

In 1980, the EEOC found no cause in 28.5 percent of the 49,225 cases it closed, while in 2009, the agency found no cause in 60.9 percent of the 85,980 cases it closed. Employers argued that the increase in the number of no-cause findings reflects an increase in the number of frivolous claims. This may be true. However, there may be another explanation for the increase in the number of no-cause findings. A General Accounting Office (GAO) study explained that the large number of no-cause findings were due to the EEOC's failure to adequately investigate between 40 and 80 percent of the cases.

The EEOC classifies resolved cases into one of two categories: merit resolutions ${ }^{2}$ and nonmerit resolutions. Nonmerit resolutions consist of cases being given a no-cause finding or dismissed because of an administrative resolution. In 1997, only 11 percent of the cases were classified as merit resolutions. From 2000 through 2009, however, the percentage of merit resolutions has ranged from a 
low of 19.5 percent (2003) to a high of 22.2 percent (2004). This means that even in the "best" years, close to 80 percent of all the claims are considered nonmeritorious.

Being classified as a merit resolution does not mean that the case has merit or that it has been resolved. Merit resolutions include cases that will be litigated and frivolous cases settled for nuisance amounts. Likewise, the "merit resolution" classification also encompasses worthy claims that are settled for nuisance amounts. In 2009, 50 percent of the merit resolutions (which is 10 percent of the total cases resolved) were settled. In fact, in 2009 the EEOC found "cause" in only 4.5 percent of the cases resolved.

Two conclusions can be drawn from these statistics. First, it is possible that numerous cases are "slipping through the cracks" at the EEOC and being dismissed without receiving proper attention. This applies to the cases resolved by either a finding of no cause or an administrative closing. The second possible conclusion to be drawn from observing the outrageously small number of meritorious cases is, as employers would argue, that the overwhelming majority of the cases filed are frivolous. Regardless, the fact is that antidiscrimination is a growth industry and all employers will face claims. Employers should therefore understand how courts analyze these cases.

\section{How Courts Analyze and Adjudicate: Discrimination Cases}

There are two types of discrimination: (1) disparate treatment, and (2) adverse impact. Disparate treatment is intentional discrimination, and adverse impact is unintentional discrimination. Adverse impact occurs when a company has a policy or practice, which is neutral on its face but has adverse impact on a protected class. For example, a company policy stating that all servers must be women discriminates on its face. Such a policy would be considered disparate treatment against men. Conversely, requiring all employees to be over 6 feet tall does not, on its face, discriminate, but could have an adverse impact against women or certain ethnic groups. Such a policy could lead to an adverse impact claim.

While statistics made available by the EEOC do not provide a breakdown of adverse impact versus disparate cases, interviews with dozens of management lawyers reveal that a very small percentage of cases are adverse impact cases. In fact, most lawyers report that despite defending hundreds of discrimination cases, they have never had an adverse impact case. Still, employers should understand the burdens of proof in adverse impact cases. 


\section{Adverse Impact}

The best way to describe the burden of proof in adverse impact cases is to examine the lead adverse impact case, Griggs v. Duke Power Company. Employer Duke Power required employees who wished to work in any job other than those in the laborers department to have, among other things, a high school diploma. This facially neutral policy, the employees argued, had an adverse impact because, according to the most recent census, only 12 percent of the African-Americans in North Carolina had graduated from high school, while the high school graduation rate for white people was 32 percent. To determine whether this constituted an adverse impact, the Supreme Court established the so-called 80 percent rule. Under the 80 percent rule, the plaintiffs can establish adverse impact if their pass rate is less than 80 percent of the majority's. The test has been made more sophisticated today, but the basic rule applies. Here, 80 percent of 32 percent is 25.60 percent. Because 25.60 percent is greater than 12 percent, the plaintiffs established a prima facie case of adverse impact. To avoid liability, the employer had to prove that being a high school graduate was a business necessity-there existed a manifest relationship between the passing of the test and success on the job, and there was no other means to achieve this. Because Duke Power could not satisfy this burden, the plaintiffs prevailed.

For you, adverse impact is an issue to keep in mind when setting neutral policies for hiring, promotion, terminations, and leaves of absence. Polices that are neutral on their face may still result in liability, and thus, before enacting such policies, employers should make sure that no protected class is adversely affected. To illustrate this point, there is a case holding that requiring employees to work one year before taking a leave of absence adversely affected women (several needed a pregnancy leave and no men were ill or injured in the time frame).

\section{Disparate Treatment}

The vast majority of discrimination cases are disparate treatment cases. There are two ways to prove disparate treatment. The first, the so-called, "pretext method" was the method used in most cases from 1981 through 2009, but the new motivating factor method may now change the way discrimination cases are litigated. We describe each in this section.

Pretext Method: Under the pretext method, the employees must prove the following:

- They are members of a protected class.

- They were minimally qualified for the position in question.

- They suffered an adverse employment action. 
- The job remained open or went to someone outside the protected class (in hiring cases), or similarly situated people engaged in similar conduct and were treated differently.

If the employee satisfies each of these elements, the employer must articulate a nondiscriminatory reason for its decision. If the employer fails to satisfy this burden of production, the employee prevails. If the employer does satisfy this burden, the employee must prove that the reason articulated was not worthy of belief (pretext) and that the real reason was discrimination. While the four steps are not onerous, prevailing under the pretext standard is not easy for employees. This is the case because proving discrimination is difficult. Most employers do not blatantly discriminate, and thus employees have a difficult time finding evidence of discrimination. Furthermore, because the burdenshifting procedure is deemed to be too complex by most jurisdictions, the usual jury instruction is simple: Did the employer make its decision because of the employee's protected class?

Motivating Factor: The second method for proving discrimination, the motivating factor method, also known as the mixed motive, has a long and complex history. The "new method" arose in 1989 when PriceWaterhouse had both illegitimate (sex) and legitimate reasons (interpersonal skills) for refusing to make Ann Hopkins a partner. The Civil Rights Act of 1991 and subsequent court cases have resulted in making this second method for proving discrimination much easier for plaintiffs to prevail. Under the motivating factor method, juries are asked two questions: (1) Did the protected class motivate the employer? and (2) would the employer have made the same decision regardless of the protected class? If the answer to the first question is no, the case is over. If the answer to the first question is yes, the jury moves to the second question. With regard to the second question, the jury is informed that a yes means no damages and no means damages.

Because of the format, most jurors believe that answering no to the first question is the same as answering yes to both questions, because in neither situation would the jury award damages. In fact, no $=$ no damages and no court costs, but yes/yes = the employee receives litigation costs and attorneys' fees (in many cases, costs and fees greatly exceed damages). Thus, juries who think they are finding for the employer are unknowingly awarding hundreds of thousands of dollars in costs and fees. Because plaintiffs' lawyers are finally learning this fact, there has been an increase in the number of plaintiffs asking for this type of instruction. Currently, the court decides the type of instruction to use.

In 2009, the Supreme Court held that the motivating factor scheme did not apply to age cases. Because courts are split if motivating factor applies to ADA and retaliation cases, it could be that the easier-to-demonstrate motivating factor scheme is limited to Title VII. Pending legislation would not only make the motivating factor scheme open to ADEA, ADA, and retaliation plaintiffs, but it would allow 
plaintiffs to choose the type of instruction they want. This will increase the costs of settlements as plaintiffs' lawyers will know that in most cases they will be able to satisfy at least the first question.

\section{The ADA}

The ADA is fundamentally different from the other federal antidiscrimination laws, which start with the premise that being a member of a protected class has no detrimental effect on an individual's ability to perform a job. The ADA is premised on the fact that those with disabilities are not equal to those without, and thus employers need to accommodate the disabled if they can perform the job. On a practical level, this difference manifests itself in three different elements of the law: (1) the definition of disability; (2) the question of qualifications; and (3) the obligation on employers to "reasonably accommodate" disabled employees.

A disability under the ADA is a physical or mental condition that substantially limits one or more major life activities, having a record of such, or being regarded as such. Because this definition creates more questions than it resolves, what constitutes a disability remains contentious, and is often determined on a case-by-case basis. For instance, we now know that HIV-positive status is considered a disability, but whether attention deficit disorder and alcoholism constitute a disability is more subjective, depending on the severity of the condition and its effect on major life activities. Homosexuals, transvestites, and transsexuals are not protected. Current drug users are also not protected. Going back to the opening vignette, you cannot be guilty of an .ADA violation if you did not know the employee was disabled.

An employer may not discriminate against an applicant or an employee if they can perform the essential functions of the job with or without a reasonable accommodation. What is an essential function is not what the employer or job description says it is. Instead, the court will answer the question.

The obligation to "reasonably accommodate" the employee is another unique feature of the ADA among discrimination laws because it imposes the cost of providing jobs for the disabled on the employer. You have an obligation under the ADA to engage in an interactive process with an employee or potential employee to determine whether you can reasonably accommodate the employee's disability. You may refuse such accommodations, however, if the requested accommodation is either unreasonable or presents an undue hardship.

If you are faced with an employee requesting an accommodation, you need to first determine whether the disability is covered by the law (consult counsel); if not, there is no obligation to 
accommodate. If so, you must engage in a process where the employee will ask for certain accommodations, and you and your counsel will determine whether they are reasonable- meaning whether the benefits to society outweigh the costs. If the benefits do outweigh the costs, you may still deny the request if you can't afford it (an undue hardship). As part of the interactive process, you need to suggest other, more affordable options. You do not need to accommodate any request, but you need to engage, consult counsel, and make a determination in accordance with the law.

\section{Sexual Harassment}

Title VII does not specifically address or prohibit "sexual harassment." However, in 1986, the United States Supreme Court in Meritor v. Vinson addressed whether employers violated Title VII when a supervisor harassed an employee on the basis of gender but the employee did not suffer any economic consequences. ${ }^{3}$ The Court held that "sexual harassment" did, in fact, violate Tide VII, regardless of whether there was an economic loss. This case began the evolution of sexual harassment law.

The Supreme Court's Meritor decisions held that there were two types of sexual harassment: (1) quid pro quo; and (2) hostile environment. Quid quo pro harassment is defined as requiring "sexual activity" in exchange for continued employment, promotions, and the like. Hostile environment is more difficult to explain. In Harris v. Forklift Systems, the U.S. Supreme Court defined hostile environment as conduct that, from the perspective of both an objective (a reasonable person) and subjective (the plaintiff) observer, was "so severe or pervasive that it created a work environment abusive to .' employees because of their race, gender, religion, or national origin." The standard from Harris is anything but clear, as Justice Scalia lamented, when he wrote that the standard: "does not seem to me a very clear standard. Be that as it may, I know of no alternative to the course the Court today has taken." In defining hostile environment, most commentators simply list examples such as staring, sexual references, and touching. Hostile environment is a moving target, and you should always check with counsel before determining whether certain allegations violate the law.

The Harris Court's holding was distilled as a two-part test requiring that: (1) the conduct is severe or pervasive, and (2) the motivation is the plaintiff's sex. In reality, however, it was the conduct and not the motivation that the Court and legal commentators emphasized as important. Motivation was not considered relevant because almost all cases consisted of men harassing women, and thus courts presumed that the conduct was "because of sex." This changed in the early 1990s with the rise of same-sex sexual harassment cases. 
After a series of lower court opinions resulted in four different laws in $A$ four different jurisdictions, the Supreme Court, in Oncale v. Sundower held that motivation was the key issue in all sexual harassment cases (opposite and same-sex). The Court held that plaintiffs could make out a case only if they were harassed "because of sex." As the Court stated, "the plaintiff... must always prove that the conduct at issue actually constituted discrimination...because of...sex."

As one of several examples to illustrate motivation, the Court held that same-sex plaintiffs could make out a case by comparing their treatment to that of the opposite sex: "a same-sex harassment plaintiff may also, of course, offer direct comparative evidence about how the alleged harasser treated members of both sexes in a mixed-sex workplace." At first glance, this method of proof seems both logical and unambiguous. In fact, it created a new, unanticipated defense for employers: the equal opportunity harasser. If disparate treatment among men and women means that motivation is unlawful, then harassing both men and women should mean that motivation is " not unlawful. That is exactly what courts in several jurisdictions have held. Thus, employers prevailed in cases where a supervisor ordered both a man and woman to have sex with that supervisor and when men displayed pornography in the workplace. In fact, sexual conduct in the form of pictures or conversations that are not directed at women should no longer be a legal concern for employers.

Oncale purported to open the doors to a whole set of new claims when it, in fact, made it more difficult for sexual harassment claims to succeed by creating a number of new defense's. This is not all good news. First, the fact that employees can display pornography or that a supervisor may lawfully sexually harass men and women does not make such actions good management practices. Moreover, employee rights advocates, plaintiffs' lawyers, and academies are not the only interested parties who are uncomfortable with the changes in the law. There are judges who seemingly do not want to follow Oncale and thus might accept ill-conceived arguments or apply tortured reasoning to achieve what they believe to be a just result. A prime example of a case where a panel of judges muddied the law and exasperated employers is Rene $v$. Mirage

In Rene, the plaintiff, a butler at the hotel, alleged that he had been sexually harassed. According to the plaintiff, the harassers' conduct included coworkers calling Rene offensive names, forcing him to look at pictures of naked men having sex, grabbing him in the crotch, and poking their fingers in his anus through his clothing. When asked why the harassers directed such conduct at him, the plaintiff stated that it was because he was gay.

Under Oncale, the case should have ended right there. Sexual orientation is not protected under federal law, and thus, harassment based on orientation is not actionable. The United States Court of 
Appeals for the Ninth Circuit did not, however, apply the law when it was faced with this case where the employee suffered from harassment that was sexual in nature and clearly both severe and pervasive. The conduct more than satisfied the criteria set out in Karris Forklift If the plaintiff were a woman and endured such treatment, any court, applying pre-Oncale law, would have focused on conduct alone and clearly found for the plaintiff. After Oncale, however, motivation had become an issue. Here, the stated motivation was not unlawful, and thus the court should have dismissed the case, but did not. Instead, the court, in a classic example of results-oriented jurisprudence, misapplied the law in general, and Oncale specifically, in order to achieve its desired result.

Rene creates a number of problems for employers. First, because Rene is a Court of Appeals decision, the holding is now the law in the Ninth Circuit. Moreover, this is an example of courts trying to make "bad law" right. The majority in Rene ignores the law, and a concurring opinion manipulates the facts. Thus, 45 years after the Civil Rights Act and 25 years after Meritor, the definition of what constitutes sexual harassment remains unclear.

Still, this story should have had a relatively happy ending for employers. In summer 1998, the Supreme Court articulated new standards for employer liability in sexual harassment cases. In the Burlington Industries v. Ellerth and Faragher v. Boca Raton opinions, the Court held that employers are liable for actions of supervisors who engage in either quid pro quo sexual harassment or hostile environment sexual harassment, regardless of whether they knew, or should have known, of the alleged conduct. Employers can escape liability if the employee did not suffer a "tangible loss" (e.g., terminated, demoted, or not promoted) and if the company satisfies the Court's affirmative defense. To do this, employers must prove that (1) the employer "exercised reasonable care to prevent and promptly correct any sexually harassing behavior" and (2) the plaintiff "unreasonably failed to take advantage of any preventive or corrective opportunities provided by the employer or to otherwise avoid harm." The problem here is that the standard was unclear. We did not know (1) what is reasonable care and (2) when an employee is unreasonable.

In 2001, my colleagues and I studied the 72 motions for summary judgment that employers filed after the Ellerth and Faragher decisions. In each motion, the companies argued that the employer satisfied, as a matter of law, the affirmative defense. We found that to exercise reasonable care, employers needed only to have a "good sexual harassment policy," defined as being written, disseminated, and providing an opportunity for employees to report to someone other than the harasser. When employers exercised reasonable care and the employee did not report, the court granted the employer's motion every time. When the employee did report harassment to an employer 
who had exercised reasonable care, the vast majority of courts found for the employer by holding that either (1) the employee was unreasonable because of delay or defect, or (2) the employer's appropriate response absolved it of liability. Thus, there were two key elements to avoiding liability: (1) have a good policy and (2) react properly to a complaint. Because employers could comply with these two prescriptions relatively simply, sexual harassment became less of a minefield for employers. This, however, may not be the case as we move forward.

Today, management attorneys report that judges are not so quick to label non-reporting employees as unreasonable, and are less likely to find fault in employees who do report. Moreover, a number of jurisdictions, including the state of California and New York City, have rejected Ellerth and hold that employers may be strictly liable for the harassment of supervisors. Thus, as time passes, the standards for harassment remain amorphous and the affirmative defense is weakening. What this means is that, as an employer, you cannot rely on the defense and must work to prevent harassment from occurring. Indeed, as seen in Rene and then evolution of state and city laws, sexual harassment may result in damages regardless of the employer's response or even the law.

\section{How to Avoid Discrimination}

Avoiding discrimination charges is impossible. Avoiding "bad facts" that could lead an investigator or jury to find for the employee is difficult. Avoiding discrimination can be accomplished. Here, we discuss the latter two points.

To avoid "bad facts," the key is document, document, document. Employers who give every employee a positive annual review, don't put discipline in employee files, or don't provide real reasons for decisions are providing plaintiffs' lawyers with all the ammunition they need to prove discrimination. Juries will see a terminated employee who is in a protected class or who engaged in a protected expression, and will believe that the class or the expression at least motivated the employers action. In such cases, the employer will end up paying its lawyer, the plaintiff's lawyer, and maybe other damages. Employers need to evaluate, discipline, document, and tell the truth.

Furthermore, to avoid bad facts, make sure that your human resource (HR) department approves major decisions. Supervisors should not hire, fire, promote, or demote employees in a vacuum. HR professionals who possess institutional knowledge are able to determine whether a perfectly reasonable decision (e.g., terminating an employee for excessive tardiness) will result in a discrimination charge because another employee, outside the class and in a different department, engaged in similar conduct and was only warned. HR can avoid these bad facts. 
Make avoiding discrimination part of your corporate culture-with such conduct never tolerated. Employers need to have published policies, train employees, and discipline violators. Along with teaching employees the company values, such actions will signal to the EEOC, judges, and juries that your company engages in proper behavior.

\footnotetext{
${ }^{1}$ D. Sherywn and G. Gilman, "Retaliation: Why an Increase in Claims Does Not Mean the Sky Is Falling," Cornell Hospitality Round-table. Proceedings (2009): 2.

${ }^{2}$ For definitions of the EEOC terms, see EEOC.gov.

${ }^{3}$ Meritor Savings Bank FSB v. Vinson, All U.S. 57 (1986).
} 